\title{
Assessment of B cell repertoire in humans
}

\author{
Yu-Chang Wu1, David Kipling², Deborah Dunn-Walters ${ }^{3}$
}

\section{Randall Division of Cell and Molecular Biophysics, King's College London School of Biomedical Science; 2. Department of Pathology, Cardiff University; 3. Department of Immunobiology, King's College London School of Medicine}

\begin{abstract}
B-cell receptor (BCR) repertoire is highly diverse. Repertoire diversity is achieved centrally by somatic recombination of immunoglobulin (Ig) genes and peripherally by somatic hypermutation and class-switching. Throughout these processes there is selection for functional gene rearrangements, selection against gene combinations resulting in self-reactive BCRs and selection for BCRs with high affinity for exogenous antigens after challenge. Hence investigation of BCR repertoires from different groups of $B$ cells can provide information on stages of B cell development and possibly shed light on the aetiology of B cell pathologies. The third complementarity determining region of the Ig heavy chain (CDR-H3) contributes the majority of amino acids to the antibody/antigen binding interface in most instances. Although CDR-H3 spectratype analysis provides information on the overall diversity of BCR repertoires, it is a fairly simple technique that analyses the relative quantities of CDR-H3 regions of each size, within a range of approximately $10-80 \mathrm{bp}$, without sequence detail and thus is limited in scope. High-throughput sequencing (HTS) techniques on the Roche 454 GS FLX Titanium system however can generate a wide coverage of Ig sequences to provide more qualitative data such as V, D and J usage as well as detailed CDR3 sequences Here we present protocols in detail for CDR-H3 spectratype analysis and HTS of human BCR repertoires.
\end{abstract}

\section{Introduction}

There are a number of processes that contribute to B cell diversity. B cell receptors (BCR), or antibodies, are encoded by two different genes that are formed of rearranged gene segments during B cell development in the bone marrow. Rearrangement of Ig heavy chain genes (IGH), in which variable (IGHV), diversity (IGHD) and joining (IGH) genes are randomly selected and spliced together occurs first [1]. During the process of somatic recombination in the $I G H$, further BCR diversity is introduced by imprecise insertion and deletion of nucleotides at the junctions of the rearranged genes, resulting in the third complementarity determining (CDR-H3) region. The CDR-H3 serves as a genetic fingerprint for an individual B-cell clone throughout its development. There is further random assortment of pairing between the IGH and the light chain genes. These can either be kappa (IGK) or lambda (IGL) genes and are formed as a result of rearrangement of variable and joining regions (either IGKV and IGKJ or IGLV and IGLJ).

The diverse repertoire created by these mechanisms can then be shaped by events external to the cell. Negative selection to remove cells with self-reactive BCRs occurs, and positive selection, to expand cells reactive to exogenous pathogen challenge also occurs. Upon activation by exogenous antigens in the periphery the B cell repertoire is further diversified by processes of somatic hypermutation (SHM), class switch 
recombination (CSR) and affinity maturation of the rearranged Ig genes. Due to the constant selection pressures on the B cell repertoire, the quality and diversity of $I G H$, $I G K$ and $I G L$ repertoires may reflect B-cell development [2-4], the history of antigen challenge $[5,6]$, the ageing process $[7,8]$ and many pathological conditions $[9,10]$.

In light of the complexity of the BCR repertoire and its enormous diversity, it has previously been difficult to analyse it in great detail. Initially, a polymerase chain reaction (PCR)-based method that amplifies the Ig gene fragment across the CDR-H3 region, termed CDR-H3 spectratype analysis, made it possible to examine the global changes of BCR repertoires with ageing [9] and in response to vaccination [6]. CDR-H3 spectratyping has also been a useful tool to detect expansion of a particular clone such as seen in lymphomas. However, it is limited to the measurement of CDR-H3 sizes and cannot provide additional information on BCR repertoires, e.g. the usage of different Ig genes, the extent of hypermutation and the exact sequence of CDR-H3. Although the traditional Sanger sequencing technique can overcome the limitations of CDR-H3 spectratyping with respect to detailed information, it does not have the advantage that spectratyping has, of being able to easily look at sufficient numbers of Ig sequences with the coverage that could reflect the diversity of BCR repertoire in humans. With the advance in next generation sequencing (NGS) technologies, several platforms are developed, capable of producing large numbers of reads that Sanger sequencing techniques cannot deliver [11]. Currently, there are two main competitors in NGS technologies: Illumina and Roche 454 platforms. As compared with the Illumina MiSeq platform that has a capacity of $15 \times 10^{6}$ reads per run with a maximum read length of 250 $\mathrm{bp}$, the upgraded Roche $454 \mathrm{GS}$ FLX+ system is able to produce long-read sequences up to $1000 \mathrm{bp}$ albeit with a smaller coverage of $1 \times 10^{6}$ reads per run. Since the length of an Ig gene from the beginning of the Ig gene, through the CDR-H3 region, to the constant region is 400 to $500 \mathrm{bp}$, the longer read length makes the 454 GS FLX+ system ideal for high-throughput sequencing (HTS) of human Ig genes. By incorporating Multiplex Identifier (MID)-containing adaptors into 454 NGS technology, several BCR repertoire libraries can be multiplexed in order to reduce the cost [12].

We have previously used CDR-H3 spectratype analysis in conjunction with HTS techniques on the 454 GS FLX Titanium system to demonstrate temporal and agerelated changes in human peripheral blood $I G H$ repertoires in response to vaccination $[6,7]$. We have also shown that $I G H$ repertoires in different B cell subsets can be distinguished from one another by HTS techniques $[13,14]$. Here we describe detailed protocols for CDR-H3 spectratyping on the ABI 3730xl DNA Analyzer system and HTS from IGH and IGK or IGL repertoires on the 454 GS FLX Titanium system using human cDNA.

\section{Materials}

Analyses of gene families by methods that use PCR are particularly at risk of cross contamination, especially if the targets are limited such as in single cell analyses. UVisolation cabinets should be used and different steps should be carried out in different areas of the lab, or in different rooms, wherever possible. A DNA/RNA-free UV isolation hood with dedicated pipettes should be reserved for preparation of Sort-Lysis Reverse 
Transcription (SLyRT) buffers and PCR mixes. Areas where PCR products are analysed by electrophoresis should be as far away from sample preparation areas as possible. PCR grade water should be used throughout for all sample preparation.

\subsection{Components for direct cDNA synthesis from cells}

Sort-Lysis Reverse Transcription (SLyRT) buffer and SuperScript III Reverse

Transcription (RT) enzyme allow direct cDNA synthesis from cells. The buffer lyses the cells, stabilises the mRNA and bypasses mRNA purification steps. The advantage of this technique is that cDNA can be obtained from single-cells or low cell numbers without substantial loss of mRNA. This does, however, mean that contaminants such as protein and genomic DNA are present along with cDNA (See Note 1).

1. Polymerase chain reaction (PCR) - grade $\mathrm{H}_{2} \mathrm{O}$.

2. Detergents Triton $\mathrm{X}$ : $5 \%$ in PCR-grade $\mathrm{H}_{2} \mathrm{O}$. (See Note 2)

3. dNTP mix: $20 \mathrm{mM}$ each of dATP, dTTP, dCTP, dGTP in PCR-grade $\mathrm{H}_{2} \mathrm{O}$ (See Note 3).

4. Random hexamers $\mathrm{pd}(\mathrm{N})_{6}$ : diluted to $50 \mathrm{ng} / \mu \mathrm{l}$ in PCR-grade $\mathrm{H}_{2} \mathrm{O}$ (Qiagen , UK).

5. RiboSafe RNase inhibitor: $40 \mathrm{U} / \mu \mathrm{l}$ (Bioline, $\mathrm{UK}$ ).

6. $0.1 \mathrm{M}$ dithiothreitol (DTT; Invitrogen, UK).

7. $5 X$ First-Strand RT buffer: $250 \mathrm{mM}$ Tris- $\mathrm{HCl}$ (pH 8.3 at RT), $375 \mathrm{mM} \mathrm{KCl}, 15$ $\mathrm{mM} \mathrm{MgCl} 2$ (Supplied with SuperScript III RT enzyme; Invitrogen, UK).

8. $25 \mathrm{U} / \mu \mathrm{l}$ SuperScript III RT enzyme (Invitrogen, UK): diluted from $200 \mathrm{U} / \mu \mathrm{l}$ with PCR-grade $\mathrm{H}_{2} \mathrm{O}$ ).

9. $200 \mu \mathrm{l}$ PCR tubes.

10. PCR thermal cycler.

\subsection{Components for polymerase chain reaction}

PCR components listed below are used to generate products for CDR-H3 spectratyping and HTS, using appropriate primers as indicated in different sections.

1. PCR-grade $\mathrm{H}_{2} \mathrm{O}$.

2. dNTP mix: $20 \mathrm{mM}$ each of dATP, dTTP, dCTP, dGTP in PCR-grade $\mathrm{H}_{2} \mathrm{O}$.

3. Phusion High-Fidelity polymerase (NEB, UK) diluted in PCR-grade water.

4. 5X GC buffer (Supplied with Phusion High-Fidelity polymerase; NEB, UK).

5. Complete primer mix: choose accordingly as indicated $[6,15]$.

6. cDNA (See Section 3.1).

7. 96-well PCR plates.

8. PCR Thermal Cyclers.

9. Thermal seals.

\subsection{Components for HTS of human immunoglobulin genes}

1. $\quad$ MID-tagged amplicons of human immunoglobulin genes (See Section 3.3).

2. Agarose gels: Dissolve 1.5 grams of agarose powder (Bioline, UK) in $100 \mathrm{ml}$ of $1 \mathrm{X}$ TAE buffer in a microwave. Once the agarose solution is cooled to $55^{\circ} \mathrm{C}$, add $10 \mu \mathrm{l}$ of 10,000 X GelStar Nucleic Acid Gel Stain (final concentration = 1X; Lonza, $\mathrm{UK}$ ) or $1 \mu \mathrm{l}$ of $10 \mathrm{mg} / \mathrm{mL}$ ethidium bromide $(\mathrm{EtBr}$; final concentration = $0.1 \mu \mathrm{g} / \mathrm{ml}$; Sigma Aldrich), as indicated. 
3. 1X Tris-Acetate-EDTA (TAE) running buffer: $40 \mathrm{mM}$ Tris-acetate and $1 \mathrm{mM}$ EDTA at pH 8.3 in distilled water (See Note 4).

4. Hyper Ladder IV Ladder (Bioline, UK).

5. Horizontal electrophoresis system, e.g. multiSUB-4 (Wolflabs, UK).

6. 6X Orange G loading dye: $10 \mathrm{mM}$ Tris- $\mathrm{HCl}(\mathrm{pH} 7.6), 0.15 \%$ orange $\mathrm{G}, 60 \%$ glycerol, $60 \mathrm{mM}$ EDTA in distilled water (See Note 5).

7. $15 \mathrm{ml}$ Falcon tubes.

8. Disposable scalpels.

9. DarkReader 46B Transilluminator instrument (LabTech, UK).

10. QIAquick gel purification kit (Qiagen, UK).

11. Qubit 2.0 Fluorometer and Qubit dsDNA HS Assay Kits (Invitrogen, UK).

12. QIAquick PCR purification kit (Qiagen, UK).

\subsection{Components for spectratype analysis of human immunoglobulin CDR-H3}

1. PCR products of human immunoglobulin genes (See section 3.2).

2. Hi-Di formamide (AppliedBiosystems, UK).

3. GeneScan 350 TAMRA Size Standard (AppliedBiosystems, UK).

4. Non-skirted, 96-well PCR plate (Cat: E1403-1200; StarLab, UK).

5. Applied Biosystems 3730xl DNA Analyzer system (AppliedBiosystems, UK).

6. GeneMapper software (AppliedBiosystems, UK).

\section{Methods}

\subsection{Direct cDNA synthesis from cells}

1. Assemble the components of SLyRT buffer as listed in Table 1. Keep SLyRT buffer on ice for immediate use or store at $-20^{\circ} \mathrm{C}$.

2. Aliquot $36 \mu \mathrm{l}$ of the SLyRT buffer into PCR tubes.

\begin{tabular}{lcccc}
\hline Table 1 & \multicolumn{3}{c}{ SLyRT buffer } \\
\hline Reagents & $\begin{array}{c}\text { Initial } \\
\text { concentration }\end{array}$ & $\begin{array}{c}1 \text { reaction } \\
\text { volumes }(\mu \mathrm{l})\end{array}$ & $\begin{array}{c}50 \text { reaction } \\
\text { volumes }(\mu \mathrm{l})\end{array}$ & $\begin{array}{c}\text { Final reaction } \\
\text { concentration }\end{array}$ \\
\hline First-Strand RT buffer & $5 \mathrm{X}$ & 8 & 400 & $1 \mathrm{X}$ \\
$\mathrm{pd}(\mathrm{N})_{6}$ & $50 \mathrm{ng} / \mu \mathrm{l}$ & 12 & 600 & $15 \mathrm{ng} / \mu \mathrm{l}$ \\
Triton X & $5 \%$ & 1 & 50 & $0.13 \%(\mathrm{v} / \mathrm{v})$ \\
RiboSafe RNase inhibitor & $40 \mathrm{U} / \mu \mathrm{l}$ & 2.5 & 125 & $2.5 \mathrm{U} / \mu \mathrm{l}$ \\
DTT & $0.1 \mathrm{M}$ & 4.5 & 225 & $11.25 \mathrm{mM}$ \\
dNTP mix & $10 \mathrm{mM}$ each & 2 & 100 & $500 \mu \mathrm{M}$ \\
PCR-graded $\mathrm{H}_{2} \mathrm{O}$ & $\mathrm{NA}$ & 6 & 300 & $\mathrm{NA}$ \\
\hline
\end{tabular}

${ }^{*}$ The final reaction concentration indicates the concentration in a total reaction volume of $40 \mu \mathrm{l}$ after cDNA, Superscript III RT enzyme and primers are added.

3. Deposit 1000-10000 B cells from the flow cytometry sorter directly into PCR tubes containing $36 \mu \mathrm{l}$ of SLyRT buffer. 
4. Invert PCR tubes several times to ensure all cells are immersed in SLyRT buffer. Briefly centrifuge the PCR tubes at $3000 \mathrm{rpm}$ for 2 minutes to collect the content.

5. Add $4 \mu \mathrm{l}$ of SuperScript III RT enzyme at $25 \mathrm{U} / \mu \mathrm{l}$, final reaction concentration $2.5 \mathrm{U} / \mu \mathrm{l}$.

6. Carry out the RT reaction on the thermal cycler, programmed as in Table 2.

\begin{tabular}{lcc}
\hline \hline $\begin{array}{l}\text { Table } 2 \\
\text { Steps }\end{array}$ & $\begin{array}{c}\text { Temperatures } \\
(\mathrm{o} \mathrm{C})\end{array}$ & $\begin{array}{c}\text { Time } \\
(\text { minutes })\end{array}$ \\
\hline Denaturation & 42 & 10 \\
Annealing & 25 & 10 \\
RT (extension) & 55 & 60 \\
RT termination & 72 & 15 \\
\hline \hline
\end{tabular}

7. Once the RT reaction is complete, centrifuge the PCR tubes at $13,000 \mathrm{rpm}$ for 5 minutes. Immediate transfer $35 \mu \mathrm{l}$ of the reaction mix to a clean PCR tubes without disturbing any cell debris at the bottom of the tube. This step reduces cellular contaminants from being carried forward to the downstream applications.

8. Add $70 \mu \mathrm{l}$ of PCR-grade $\mathrm{H}_{2} \mathrm{O}$ to $35 \mu \mathrm{l}$ of the reaction mix and pipette several times to mix (See Note 1).

9. Store samples at $-20^{\circ} \mathrm{C}$.

\subsection{Spectratype analysis of human immunoglobulin CDR-H3 regions}

Spectratype analysis allows investigation of BCR repertoires by measuring relative quantities of different sizes of CDR-H3 regions. It is relatively cheap and quick compared to HTS techniques. If HTS is employed the information will be in the sequencing data and spectratyping will not be necessary. This section includes generation of PCR products, which span across human immunoglobulin CDR-H3 regions and into the 5 '-end of the constant region (Figure 1), and preparation of samples prior to fragment size analysis on the Applied Biosystems 3730xl DNA Analyzer system.

1. Assemble reagents for PCR master mix and vortex to mix thoroughly. Change the 3'-end primer for different isotypes of the heavy chains. The concentration for each reagent is shown in Table 3.

\begin{tabular}{lcccc}
\hline \hline \multicolumn{1}{c}{ Table 3} & \multicolumn{4}{c}{ Spectratype PCR reaction mix $(25 \mu \mathrm{l}$ per reaction $)$} \\
\hline Reagents & $\begin{array}{c}\text { Initial } \\
\text { concentration }\end{array}$ & $\begin{array}{c}1 \text { reaction } \\
\text { volumes }(\mu \mathrm{l})\end{array}$ & $\begin{array}{c}110 \text { reaction } \\
\text { volumes }(\mu \mathrm{l})\end{array}$ & $\begin{array}{c}\text { Final reaction } \\
\text { concentration }\end{array}$ \\
\hline GC buffer & $5 \mathrm{X}$ & 5 & 550 & $1 \mathrm{x}$ \\
1:20 Phusion polymerase & $0.25 \mathrm{U} / \mu \mathrm{l}$ & 2 & 220 & $0.02 \mathrm{U} / \mu \mathrm{l}$ \\
dNTP mix & $20 \mathrm{mM} \mathrm{each}$ & 0.5 & 55 & $400 \mu \mathrm{M}$ each \\
5'- end FW3-FAM & $10 \mu \mathrm{M}$ & 1 & 110 & \\
primer* & $10 \mu \mathrm{M}$ & 1 & 110 & $400 \mathrm{nM}$ \\
3'- end constant primer* & $\mathrm{NA}$ & 13.5 & 1485 & $400 \mathrm{nM}$ \\
PCR-graded $\mathrm{H}_{2} \mathrm{O}$ & & & & $\mathrm{NA}$ \\
\hline \hline
\end{tabular}

\section{${ }^{*}$ See Note 6.}

\pm The finial reaction concentration indicates the concentration after cDNA is added. 
2. Aliquot the PCR master mix to a 96-well plate, $23 \mu \mathrm{l}$ per well.

3. Add cDNA to the 96-well PCR1 plate, $2 \mu$ l per well (See Note 7; See Section 3.1).

4. Seal PCR plates with thermal seals and carry out PCR reaction on the thermal cycler programmed as Table 4.

\begin{tabular}{|c|c|c|c|}
\hline Steps & & Temperature $\left({ }^{\circ} \mathrm{C}\right)$ & Time (sec) \\
\hline \multicolumn{2}{|c|}{ Initial denaturation } & 95 & 60 \\
\hline \multirow{3}{*}{$\begin{array}{l}\tilde{d} \\
\tilde{u} \\
0 \\
\text { L } \\
\sim\end{array}$} & Denaturation & 95 & 45 \\
\hline & Annealing & $61(\operatorname{Ig} A) ; 55(\operatorname{IgG} \& \operatorname{Ig} M)$ & 45 \\
\hline & Extension & 72 & 45 \\
\hline \multicolumn{2}{|c|}{ Final extension } & 72 & 600 \\
\hline
\end{tabular}

5. Briefly centrifuge the PCR plate to collect the content.

6. In a non-skirted PCR plate, add $3 \mu \mathrm{l}$ of the PCR products to $1.5 \mu \mathrm{l}$ GeneScan 350 TAMRA Size Standard and $13.5 \mu \mathrm{l} \mathrm{Hi-Di} \mathrm{formamide} \mathrm{per} \mathrm{well.} \mathrm{Pipette} \mathrm{up} \mathrm{and}$ down a couple of times to mix thoroughly (See Note 8).

7. Centrifuge the PCR plate to collect the content and ensure no air bubbles are present.

8. Place the plate on the 3730xl DNA Analyzer system for spectratyping (See Note 9).

9. Collect and analyse the data on the GeneMapper software according to the manufacturer's instructions (See Note 10).

\subsection{HTS of human immunoglobulin genes}

HTS allows analysis of BCR repertoires in detail, including the distribution of CDR-H3 sizes. This section includes production of immunoglobulin gene amplicons, gel purification of amplicons, assembly of multiple amplicons (up to twelve MID barcodes per sequencing sample) and enrichment of pooled amplicons. Sequencing on the $454 \mathrm{GS}$ FLX Titanium instrument is performed by LGC Genomics, where each sequencing sample (containing 12 MIDS) is run on $1 / 16^{\text {th }}$ of a chip. Take care to avoid crosscontamination between samples. Each research (cDNA) sample that is required to be distinguishable from other research samples needs to be amplified with its own MID tag. Within that MID tag it is possible to combine three different isotypes of heavy chains, and kappa and lambda light chains for that particular research sample, since these can be distinguished later by their sequence. (See Note 11)

1. To generate MID-tagged amplicons, perform semi-nested PCR reactions (Figure 2:).

\section{PCR1}

1.1a. Assemble reagents for PCR1 master mix, and vortex to mix thoroughly. Change primer mix accordingly to produce different type of amplicons (different heavy chain classes or kappa light chain or lambda light chains). The concentration for each reagent is shown in Table 5. 


\begin{tabular}{|c|c|c|c|c|}
\hline Table 5 & HTS P & Reaction mix & $\mu \mathrm{l}$ per reactio & \\
\hline Reagents & $\begin{array}{c}\text { Initial } \\
\text { concentration }\end{array}$ & $\begin{array}{c}1 \text { reaction } \\
\text { volume }(\mu \mathrm{l})\end{array}$ & $\begin{array}{l}110 \text { reaction } \\
\text { volumes }(\mu \mathrm{l})\end{array}$ & $\begin{array}{c}\text { Final reaction } \\
\text { concentration }\end{array}$ \\
\hline GC buffer & $5 X$ & 5 & 550 & $1 \mathrm{x}$ \\
\hline 1:40 Phusion & $0.125 \mathrm{U} / \mu \mathrm{l}$ & 5 & 550 & $0.025 \mathrm{U} / \mu \mathrm{l}$ \\
\hline dNTP mix & $20 \mathrm{mM}$ each & 0.25 & 27.5 & $200 \mu \mathrm{M}$ each \\
\hline $\begin{array}{l}\text { Primer mix* } \\
5^{\prime} \text {-end variable } \\
\text { primers }\end{array}$ & $835 \mathrm{nM}$ each & 1.25 & 125 & \\
\hline $\begin{array}{l}\text { 3'- end constant } \\
\text { primer }\end{array}$ & $5 \mu \mathrm{M}$ & & & $\begin{array}{c}41.75 \mathrm{nM} \text { each } \\
250 \mathrm{nM}\end{array}$ \\
\hline PCR-grade $\mathrm{H}_{2} \mathrm{O}$ & NA & 10.5 & 1155 & NA \\
\hline
\end{tabular}

\section{${ }^{*}$ See Note 12.}

\pm The final reaction concentration indicates the concentration after cDNA and primers are added.

1.1b. Aliquot the PCR1 master mix into a 96-well PCR1 plate, $22 \mu \mathrm{l}$ per well.

1.1c. Add 1:3 diluted cDNA (See Section 3.1) to the 96-well PCR1 plate, $3 \mu$ per well. Use one PCR plate for each type of amplicon (i.e. either IgA, IgG, IgM, IgK, or IgL) and perform 8 PCR1 reactions for each research sample.

1.1d. Seal PCR plates with thermal seals and carry out PCR1 reaction on the thermal cycler programmed as in Table 6.

\begin{tabular}{|c|c|c|c|}
\hline \multicolumn{2}{|c|}{ Steps } & $\begin{array}{l}\text { Temperature } \\
\left({ }^{\circ} \mathrm{C}\right)\end{array}$ & $\begin{array}{l}\text { Time } \\
\text { (sec) }\end{array}$ \\
\hline \multicolumn{2}{|c|}{ Initial denaturation } & 98 & 30 \\
\hline \multirow{3}{*}{ 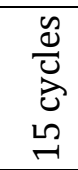 } & Denaturation & 98 & 10 \\
\hline & Annealing & 58 & 15 \\
\hline & Extension & 72 & 30 \\
\hline \multicolumn{2}{|c|}{ Final extension } & 72 & 600 \\
\hline
\end{tabular}

1.1e. Briefly centrifuge plates to collect the contents and store the plate at $-20^{\circ} \mathrm{C}$.

\section{PCR2}

1.2a. Assemble reagents for PCR2 master mix (110 reactions), and vortex to mix thoroughly. The concentration for each reagent is shown in Table 7.

\begin{tabular}{lcccc}
\hline \hline & Table 7 & \multicolumn{4}{c}{ HTS PCR2 Reaction mix $(20 \mu \mathrm{l}$ per reaction $)$} & \\
\hline \multirow{2}{*}{ Reagents } & $\begin{array}{c}\text { Initial } \\
\text { concentration }\end{array}$ & $\begin{array}{c}1 \text { reaction } \\
\text { volume }(\mu \mathrm{l})\end{array}$ & $\begin{array}{c}110 \text { reaction } \\
\text { volumes }(\mu \mathrm{l})\end{array}$ & $\begin{array}{c}\text { Final reaction } \\
\text { concentration }\end{array}$ \\
\hline GC buffer & $5 \mathrm{X}$ & 4 & 440 & $1 \mathrm{x}$ \\
1:20 Phusion & $0.25 \mathrm{U} / \mu \mathrm{l}$ & 2 & 220 & $0.025 \mathrm{U} / \mu \mathrm{l}$ \\
dNTP mix & $20 \mathrm{mM}$ each & 0.2 & 22 & $200 \mu \mathrm{M}$ each
\end{tabular}


\pm The final reaction concentration indicates the concentration after sample and primers are added.

1.2b. Aliquot the PCR2 master mix to 96-well PCR plates, $17 \mu \mathrm{l}$ per well.

1.2c. Add MID-containing primer mix (See Note 13) to the 96-well PCR2 plate, 1 $\mu$ l per well.

1.2d. Add $2 \mu$ l per well of PCR1 products accordingly to the 96-well PCR plate. For each PCR1 product, perform duplicate of PCR2 reactions. This results in 16 wells of final PCR product per amplicon type and research sample to be purified for sequencing. This, together with the short PCR amplification reactions, is designed such that larger amounts of product for sequencing can be obtained while at the same time maximising the representation of in vivo diversity over in vitro PCR amplification processes.

1.2e. Seal PCR plates with thermal seals and carry out the PCR2 reaction on the thermal cycler programmed as in Table 8.

\begin{tabular}{|c|c|c|c|}
\hline \multicolumn{2}{|c|}{ Steps } & $\begin{array}{c}\text { Temperature } \\
\left({ }^{\circ} \mathrm{C}\right)\end{array}$ & $\begin{array}{l}\text { Time } \\
\text { (sec) }\end{array}$ \\
\hline \multicolumn{2}{|c|}{ Initial denaturation } & 98 & 30 \\
\hline \multirow{3}{*}{$\begin{array}{l}\tilde{y} \\
\frac{0}{0} \\
0 \\
0 \\
0\end{array}$} & Denaturation & 98 & 10 \\
\hline & Annealing & 58 & 15 \\
\hline & Extension & 72 & 30 \\
\hline \multicolumn{2}{|c|}{ Final extension } & 72 & 600 \\
\hline
\end{tabular}

1.2f. Briefly centrifuge plates to collect the contents and store the plate until required at

$-20^{\circ} \mathrm{C}$.

2. Combine all 16 wells of PCR2 products ( $20 \mu \mathrm{l}$ per well; $320 \mu \mathrm{l}$ in total) into one $15 \mathrm{ml}$ Falcon tube. Each $15 \mathrm{ml}$ Falcon tube therefore contains $320 \mu \mathrm{l}$ of PCR2 products in total per amplicon type (having the same MID and type of Ig gene amplified from the same research sample).

3. Add $64 \mu \mathrm{l}$ of $6 \mathrm{X}$ orange $\mathrm{G}$ loading dye per tube to the combined PCR2 products.

4. Preheat samples at $98^{\circ} \mathrm{C}$ on a heat block for 5-10 minutes.

5. Place $1.5 \%$ agarose/TAE gels containing $1 \mathrm{X}$ GelStar Nucleic Acid Gel Stain in the horizontal electrophoresis apparatus filled with 1X TAE buffer.

6. Load the preheated samples on the gel and use $5 \mu \mathrm{l}$ of Hyper Ladder IV Ladder. Separate DNA fragments by electrophoresis at $100 \mathrm{~V}$ for 60 minutes.

7. Visualise DNA fragments using the DarkReader 46B Transilluminator instrument.

8. Excise fragments of the right size (Figure 3), using sterile scalpels and transfer gel slices into $15 \mathrm{ml}$ Falcon tubes.

9. Extract DNA using the QIAquick gel purification kit, according to the manufacturer's instructions, except for the following changes: 
9a. Incubate gel slices in $5 \mathrm{ml}$ of Buffer QG per amplicon type in $15 \mathrm{ml}$ Falcon tubes at $55^{\circ} \mathrm{C}$. Vortex frequently until gel slices are melted. Expect approximately $6 \mathrm{ml}$ of the solutions in total per amplicon type in the $15 \mathrm{ml}$ Falcon tube.

9b. Use one QIAquick spin column per amplicon type: apply $750 \mu \mathrm{l}$ of the solution to the QIAquick spin column and centrifuge at 13,000 rpm for 30 seconds.

Collect, rather than discard, the flow-through in a separate $15 \mathrm{ml}$ Falcon tube. Repeat this process until all mixture has been applied to the same column, spun and recollected in a separate $15 \mathrm{ml}$ Falcon tube.

9c. Apply the flow-through $(750 \mu \mathrm{l}$ at a time) back to the same spin column, spin at $13,000 \mathrm{rpm}$ and discard the second flow through.

9d. Wash the spin column with $750 \mu$ Buffer PE by centrifuging at $13,000 \mathrm{rpm}$ for 1 minute.

9e. Add $55 \mu \mathrm{l}$ PCR-grade $\mathrm{H}_{2} \mathrm{O}$ to the column membrane and leave at RT for 3 minutes.

9f. Centrifuge the column at 13,000 rpm for 1 minute and collect the elution in 1.5 $\mathrm{ml}$ microcentrifuge tube.

9g. Add additional $55 \mu \mathrm{l}$ of PCR-grade water to the same column membrane and leave at RT for 3 minutes.

$9 \mathrm{~h}$. Spin to collect the elution in the same $1.5 \mathrm{ml}$ microcentrifuge tube. In total, approximately $100 \mu \mathrm{l}$ of elution will be collected in one $1.5 \mathrm{ml}$ microcentrifuge tube.

10. Measure the concentration and quality of the gel-purified products for each amplicon type using the Qubit dsDNA HS Assay Kits on the Qubit 2.0 Fluorometer.

11. Assemble the multiple amplicons into one sequencing sample.

When 12 MID barcodes are used, transfer 900 ng of products per MID to a clean $1.5 \mathrm{ml}$ microcentrifuge tube, i.e. a total of 10,800 $\mathrm{ng}$ are pooled from 12 MID types (See Note 14). If amplicons of multiple isotypes of heavy chain and light chains are allocated to the same MID barcode, divide 900 ng equally. Examples for the amount (in ng) of gel-purified products for pooling multiple amplicon types are listed in Table 9.

\begin{tabular}{lcccccc}
\hline \hline Table 9 & IgA & IgG & IgM & IgK & IgL & $\begin{array}{c}\text { Total } \\
\text { (ng/MID) }\end{array}$ \\
\hline MID 1 & 900 & NA & NA & NA & NA & 900 \\
MID 2 & 300 & 300 & 300 & NA & NA & 900 \\
MID 3 & NA & NA & NA & 450 & 450 & 900 \\
MID 4 & 180 & 180 & 180 & 180 & 180 & 900 \\
MID 5 & NA & 450 & NA & NA & 450 & 900 \\
MID 6 & 225 & 225 & 225 & NA & 225 & 900 \\
MID 7 & 180 & 180 & 180 & 180 & 180 & 900 \\
MID 8 & 180 & 180 & 180 & 180 & 180 & 900 \\
MID 9 & 180 & 180 & 180 & 180 & 180 & 900 \\
MID 10 & 180 & 180 & 180 & 180 & 180 & 900 \\
MID 11 & 180 & 180 & 180 & 180 & 180 & 900 \\
MID 12 & 180 & 180 & 180 & 180 & 180 & 900 \\
\hline \hline
\end{tabular}


12. Enrich pooled products using the QIAquick PCR purification kit, according to the manufacture's instructions. This step is carried out in a similar way as Step 9, except Buffer PBI is used to mix with the pooled gel-purified solutions. Elute products in two lots of $55 \mu \mathrm{l}$ PCR-grade water as Step 9.

13. Measure the concentration and quantity of the pooled mixture as Step 10. The pooled mixture for the final sequencing sample needs to be a total of at least 5 $\mu \mathrm{g}$ at a concentration of $100 \mathrm{ng} / \mu \mathrm{l}$.

14. Analyse $100 \mathrm{ng}$ of the final sequencing sample on $1.5 \%$ agarose/TAE/EtBr gel to check that all primers have been removed before HTS is carried out. Samples are sent for sequencing according to the instructions from the contractor (LGC Genomics).

15. Sequence data are output as the .FASTA format and the raw FASTA files are analysed in a three-stage approach $[6,15]$.

15a. First, individual potential IGH sequences are subjected to a series of quality control (QC) assessments with the aim of identifying sequences that implausible from a biological perspective (for example, an interval between the two Ig primers that is too short based on known Ig gene sequences, or an arrangement or spacing of internal Ig motifs that is incompatible with known Ig gene sequences), contain evidence of PCR or library construction artefacts (such as internal MID sequences, or mis-matches between the start and finish MID motifs), or are too short to provide data on isotype or CDR-H3 region. Sequences that fail this initial QC step are excluded from further analysis.

$15 \mathrm{~b}$.Sequences that pass this quality control are then edited to remove any terminal adapter and MID sequences added as part of the sequencing protocol, and each sequence is re-named so as to capture and embed sample information based on the MID tag. Sequences are then passed in bulk to HighV-QUEST $[16,17]$. This is a freely available online resource (http://www.imgt.org/HighVQUEST/index.action) that analyses each sequence with reference to a database of human Ig sequences and returns a summary file cataloguing a range of outputs for each sequence including V, D and J gene usage and CDR-H3 sequence and length.

15c. The V-QUEST output file is then parsed locally to further summarise the data for each sequence regarding gene usage. The amino acid sequence of the CDR$\mathrm{H} 3$ junction peptide is extracted and analysed for a range of physicochemical properties (hydrophobicity, charge, amino acid use, and so forth) using a locally scripted version of the ProtParam tool that is available on the ExPASy server [18]. In addition, the DNA sequence of the CDR3 region is used, in combination with hierarchical clustering and tree cutting, to identify clusters ("clones") of sequences that share related CDR-H3 sequences. Further analysis highlights clones that span multiple isotypes (indicative of class switching). Finally, a single sequence from each clone is identified that represents the most common pattern of gene usage as a reference sequence for further analysis, such as regarding overall repertoire (See Note 15).

\section{Notes}


1. At low cell numbers this is not an issue but if high cell numbers (over 6,000 cells) are used, the subsequent PCR steps may be more efficient if the cDNA sample synthesised using SLyRT buffer is diluted 1 in $3(35 \mu \mathrm{l}+70 \mu \mathrm{l})$ with PCR grade water.

2. $100 \%$ Triton is difficult to pipette due to high viscosity so it may be helpful to cut the end of the pipette tip with a scalpel to make it wider, and pipette slowly.

3. Add $200 \mu \mathrm{l}$ each of dATP, dTTP, dCTP, dGTP in (20 mM each; Promega, UK) to $200 \mu \mathrm{l}$ DNase/RNase-free $\mathrm{H}_{2} \mathrm{O}$ and vortex to mix.

4. 1X TAE running buffer contained $40 \mathrm{mM}$ Tris-borate and $1 \mathrm{mM}$ EDTA. To make 50x TAE, $242 \mathrm{~g}$ Tris base, $57.1 \mathrm{ml}$ glacial acetic acid (Merck, UK) and $100 \mathrm{ml}$ EDTA (pH 8.0) were dissolved in 1 litre distilled water, and then filtered to sterilise. 1 volume of 50x TAE was then diluted with 49 volumes of distilled water to make $1 \mathrm{x}$ TAE.

5. To make 6X Orange loading dye, add 0.25 g Orange G (Sigma Aldrich, UK) to 30 $\mathrm{ml}$ glycerol and $70 \mathrm{ml}$ distilled water in a $50 \mathrm{ml}$ Falcon tube and vortex to mix thoroughly.

6. Primers for spectratyping are listed in Table 10 below.

\begin{tabular}{cc}
\hline \hline Table 10 & Sequence (5' to 3') \\
\hline 5'-end primer & \\
FW3-FAM & ACACGGCTGTGTATTACTGT \\
& in combination with \\
3'-end primer & \\
IGHA or & GGAAGAAGCCCTGGACCAGGC \\
IGHG or & CACCGTCACCGGTTCGG \\
IGHM & CAGGAGACGAGGGGGAA \\
\hline \hline
\end{tabular}

7. cDNA can either obtained using SLyRT buffer or commercially available kits, e.g. RNeasy Mini kit (Qiagen, UK) in conjunction with First Strand cDNA synthesis kit (Invitrogen, UK). The amount of cDNA used for PCR should be optimised.

8. If necessary, PCR products for spectratype analysis can be analysed on $10 \%$ polyacrylamide gels to check before running on the analyser.

9. FW3-FAM primers are light sensitive and should avoid exposure to the light. PCR products for spectratyping should not be kept in the fridge longer than 3 days before analysis, as the signals from the 3730xl DNA Analyzer system could be reduced.

10. The primers for the $\mathrm{C}$ regions in the different isotypes do not all bind at the same distance away from the joining region. Therefore a correction will need to be applied to normalise the data. To get the actual CDR-H3 size without primer sequences, subtract 70bp (IGHM primers) or 146bp (IGHG primers) or 126bp (IGHA primers).

11. An example of experimental organisation for HTS samples is shown in Table 11, where 12 research samples are multiplexed as one sequencing sample.

\begin{tabular}{lllcccccc}
\hline Table & & & & & & & & \\
11 & & & & & & & \\
Patient & Tissue & Cell type & IgM & IgG & IgA & kappa & lambda & Multiplex ID \\
\hline A & Blood & Transitional B cell & x & NA & NA & x & x & MID1 \\
\hline
\end{tabular}




\begin{tabular}{|c|c|c|c|c|c|c|c|c|}
\hline & Blood & Naive B cell & $\mathrm{x}$ & NA & NA & $\mathrm{x}$ & $\mathrm{x}$ & MID2 \\
\hline & Blood & Memory B cell & $\mathrm{x}$ & $\mathrm{x}$ & $\mathrm{x}$ & $\mathrm{x}$ & $\mathrm{x}$ & MID3 \\
\hline & Blood & Plasma cell & $\mathrm{x}$ & $\mathrm{x}$ & $\mathrm{x}$ & $\mathrm{x}$ & $\mathrm{x}$ & MID4 \\
\hline \multirow[t]{4}{*}{ B } & Blood & Transitional B cell & $\mathrm{x}$ & NA & NA & $\mathrm{x}$ & $\mathrm{x}$ & MID5 \\
\hline & Blood & Naive B cell & $\mathrm{x}$ & NA & NA & $\mathrm{x}$ & $\mathrm{x}$ & MID6 \\
\hline & Blood & Memory B cell & $\mathrm{x}$ & $\mathrm{x}$ & $\mathrm{x}$ & $\mathrm{x}$ & $\mathrm{x}$ & MID7 \\
\hline & Blood & Plasma cell & $\mathrm{x}$ & $\mathrm{x}$ & $\mathrm{x}$ & $\mathrm{x}$ & $\mathrm{x}$ & MID8 \\
\hline \multirow[t]{4}{*}{$\mathrm{C}$} & Blood & Transitional B cell & $\mathrm{x}$ & NA & NA & $\mathrm{x}$ & $\mathrm{x}$ & MID9 \\
\hline & Blood & Naive B cell & $\mathrm{x}$ & NA & NA & $\mathrm{x}$ & $\mathrm{x}$ & MID10 \\
\hline & Blood & Memory B cell & $\mathrm{x}$ & $\mathrm{x}$ & $\mathrm{x}$ & $\mathrm{x}$ & $\mathrm{x}$ & MID11 \\
\hline & Blood & Plasma cell & $\mathrm{x}$ & $\mathrm{x}$ & $\mathrm{x}$ & $\mathrm{x}$ & $\mathrm{x}$ & MID12 \\
\hline
\end{tabular}

12. PCR1 primer mix (Table 12) contains 5 '-end multiplex primers that anneal to all families of the variable regions and 3'-end primers that anneal to the constant region. $1.25 \mu \mathrm{l}$ of the primer mix, containing $835 \mathrm{nM}$ each of $5^{\prime}$-end primers and $5 \mu \mathrm{M} 3$ '-end primer, is used in a final reaction volume of $25 \mu \mathrm{l}$, to give the final concentrations at $41.75 \mathrm{nM}$ each and $250 \mathrm{nM}$, respectively.

\begin{tabular}{|c|c|c|c|c|c|}
\hline $\begin{array}{l}\text { Table } 12 \\
\text { 5'-end } \\
\text { primer }\end{array}$ & $\begin{array}{l}\text { Sequence } \\
\left.\text { (5' to } 3^{\prime}\right)\end{array}$ & & $\begin{array}{l}\text { 3'-end } \\
\text { primer } \\
\text { s }\end{array}$ & $\begin{array}{l}\text { Sequence } \\
\left(5^{\prime} \text { to } 3^{\prime}\right)\end{array}$ & Amplicon type \\
\hline IGHV1 & $\begin{array}{l}\text { CCTCAGTGAAGGTCTCCTGCAAG } \\
\text { G }\end{array}$ & \multirow{6}{*}{ 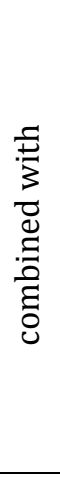 } & IGHA & GGCTCCTGGGGGAAGAAGCC & IgA \\
\hline IGHV2 & $\begin{array}{l}\text { TCCTGCGCTGGTGAAACCCACAC } \\
\text { A }\end{array}$ & & & or & \multirow[b]{2}{*}{$\operatorname{IgG}$} \\
\hline IGHV3 & GGTCCCTGAGACTCTCCTGTGCA & & IGHG & GCGCCTGAGTTCCACGACAC & \\
\hline IGHV4 & $\begin{array}{l}\text { TCGGAGACCCTGTCCCTCACCTG } \\
\text { C }\end{array}$ & & \multirow{3}{*}{ IGHM } & or & \multirow{3}{*}{$\operatorname{IgM}$} \\
\hline IGHV5 & CAGTCTGGAGCAGAGGTGAAA & & & \multirow[t]{2}{*}{ GGGGAATTCTCACAGGAGAC } & \\
\hline IGHV6 & $\begin{array}{l}\text { CCTGTGCCATCTCCGGGGACAGT } \\
\text { G }\end{array}$ & & & & \\
\hline IGKV1 & CATCCAGWTGACCCAGTCTCC & \multirow{6}{*}{ 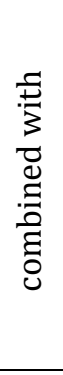 } & \multirow{6}{*}{ IGKC } & \multirow{6}{*}{$\begin{array}{l}\text { CCTTCCACTGTACTTTGGCCT } \\
\mathrm{C}\end{array}$} & \multirow{6}{*}{$\begin{array}{l}\text { Kappa heavy } \\
\text { chain }\end{array}$} \\
\hline IGKV2 & GATATTGTGATGACCCAGWCT & & & & \\
\hline IGKV3 & GACRCAGTCTCCAGCCACCCTG & & & & \\
\hline IGKV4 & GACATCGTGATGACCCAGTCT & & & & \\
\hline IGKV5 & GAAACGACACTCACGCAGTCT & & & & \\
\hline IGKV6 & GAAATTGTGCTGACTCAGTCT & & & & \\
\hline IGLV1 & CAGTCTGTGCTGACKCAGCC & \multirow{5}{*}{ 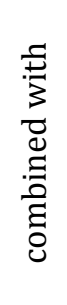 } & \multirow{5}{*}{ IGLC } & \multirow{5}{*}{ GCCACTGTCACRGCTCCCGGG } & \multirow{5}{*}{$\begin{array}{l}\text { Lambda light } \\
\text { chain }\end{array}$} \\
\hline IGLV2 & CAGTCTGCCCTGACTCAGCC & & & & \\
\hline IGLV3 & CCTATGAGCTGACWCAGCCAC & & & & \\
\hline IGLV4/5 & CAGCCTGTGCTGACTCARYC & & & & \\
\hline IGLV6 & CCAGNCTGTGSTGACTCAG & & & & \\
\hline
\end{tabular}

13. PCR2 primers are comprised of gene specific sequences and non-gene specific, 10-base MID sequence motifs. PCR2 primer mix contains 5'-end multiplex MID-containing primers that anneal to all families of the variable 
regions and 3'-end MID-containing primers that anneal to the constant region $(1 \mu \mathrm{l}$ of the MID-containing primer mix, containing $835 \mathrm{nM}$ each of 5 '-end primers and $5 \mu \mathrm{M} 3$ '-end primer, is used in a final reaction volume of $20 \mu \mathrm{l}$, to give the final concentrations at $41.75 \mathrm{nM}$ each and $250 \mathrm{nM}$, respectively. Each primer mix contains only one MID barcode for amplification from one research sample and a total of 12 different MID barcodes can be used for 12 different research samples (Table 13).

\begin{tabular}{ll}
\hline \hline Table 13 & Sequence (5' to 3') \\
\hline MID 1 & acgagtgcgt \\
MID 2 & acgctcgaca \\
MID 3 & agacgcactc \\
MID 4 & agcactgtag \\
MID 5 & atcagacacg \\
MID 6 & atatcgcgag \\
MID 7 & cgtgtctcta \\
MID 8 & ctcgcgtgtc \\
MID 9 & tagtatcagc \\
MID 10 & tctctatgcg \\
MID 11 & tgatacgtct \\
MID 12 & tactgagcta \\
\hline \hline
\end{tabular}

The gene specific sequences of 5 '-end primers for the heavy and light chains and 3 '-end primers for the light chains are same as PCR1. The genespecific sequences in the 3'-end primers of the heavy chains anneal for PCR2 reactions (Table 14) to the template more upstream to those used in PCR1.

\begin{tabular}{ll}
\hline \hline Table & \\
14 & Sequence (5' to 3') \\
\hline IGHA" & GGAAGAAGCCCTGGACCAGGC \\
IGHG" & CACCGTCACCGGTTCGGGG \\
IGHM" & CAGGAGACGAGGGGGAAAAGG \\
\hline \hline
\end{tabular}

For space consideration, MID1-containing primers for IgA are shown as an example (Table 15).

\begin{tabular}{|c|c|c|c|}
\hline $\begin{array}{l}\text { Table } 15 \\
5 \text { '-end primer }\end{array}$ & $\begin{array}{l}\text { Sequence } \\
\left.\text { (5' to } 3^{\prime}\right)\end{array}$ & & $\begin{array}{l}\text { 3'-end primer } \\
\text { Sequence (5' to 3') }\end{array}$ \\
\hline MID1:IGHV1 & $\begin{array}{l}\text { acgagtgcgtCCTCAGTGAAGGTCTCCTGCAAG } \\
\text { G }\end{array}$ & \multirow{6}{*}{ 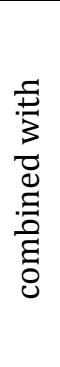 } & \multirow{6}{*}{$\begin{array}{l}\text { MID1:IGHA" } \\
\text { acgagtgcgtGGCTCCTGGGGGAAGAAGCC }\end{array}$} \\
\hline MID1:IGHV2 & acgagtgcgtTCCTGCGCTGGTGAAACCCACACA & & \\
\hline MID1:IGHV3 & acgagtgcgtGGTCCCTGAGACTCTCCTGTGCA & & \\
\hline MID1:IGHV4 & acgagtgcgtTCGGAGACCCTGTCCCTCACCTGC & & \\
\hline MID1:IGHV5 & acgagtgcgtCAGTCTGGAGCAGAGGTGAAA & & \\
\hline MID1:IGHV6 & acgagtgcgtCCTGTGCCATCTCCGGGGACAGTG & & \\
\hline
\end{tabular}


14. Although it only requires $5 \mathrm{ng}(50 \mathrm{ng} / \mu \mathrm{l})$ in total of the purified pooled mixture to be sequenced as one sequencing sample using a $1 / 16^{\text {th }}$ microchip on the 454 GS FLX Titanium platform, a significant amount of products can be lost during the gel purification and enrichment steps. It is therefore ideal to prepare more products than $5 \mathrm{ng}$ in total before gel purification and enrichment steps and then dilute final sequencing sample to the concentration of $50 \mathrm{ng} / \mu \mathrm{l}$.

15. All the analyses (other than online submission to HighV-Quest) are performed using custom scripts written in the open-source R language [19] using additional packages, notable Biostrings, from the Bioconductor project [20]. All the R/Bioconductor packages are open source and freely available. A full work flow, including custom R scripts to perform the preV-QUEST quality control filtering and editing, the parsing of the V-QUEST output files and ProtParam analysis, and the clustering-based clone identification, is available from the authors (KiplingD@cardiff.ac.uk) upon request.

\section{References}

[1] I. Sanz, J Immunol, 147 (1991) 1720-1729.

[2] S. Tonegawa, Nature, 302 (1983) 575-581.

[3] F.M. Raaphorst, C.S. Raman, J. Tami, M. Fischbach, I. Sanz, International immunology, 9 (1997) 1503-1515.

[4] J.M. Volpe, T.B. Kepler, Immunome research, 4 (2008) 3.

[5] K. Larimore, M.W. McCormick, H.S. Robins, P.D. Greenberg, J Immunol, 189 (2012) 32213230.

[6] A. Ademokun, Y.C. Wu, V. Martin, R. Mitra, U. Sack, H. Baxendale, D. Kipling, D.K. DunnWalters, Aging cell, 10 (2011) 922-930.

[7] Y.C. Wu, D. Kipling, D.K. Dunn-Walters, Frontiers in immunology, 3 (2012) 193.

[8] A.M. Cuisinier, V. Guigou, L. Boubli, M. Fougereau, C. Tonnelle, Scandinavian journal of immunology, 30 (1989) 493-497.

[9] K.L. Gibson, Y.C. Wu, Y. Barnett, O. Duggan, R. Vaughan, E. Kondeatis, B.O. Nilsson, A. Wikby, D. Kipling, D.K. Dunn-Walters, Aging cell, 8 (2009) 18-25.

[10] R.C. Tschumper, Y.W. Asmann, A. Hossain, P.M. Huddleston, X. Wu, A. Dispenzieri, B.W. Eckloff, D.F. Jelinek, Oncotarget, 3 (2012) 502-513.

[11] A.A. Warsame, H.C. Aasheim, K. Nustad, G. Troen, A. Tierens, V. Wang, U. Randen, H.P. Dong, S. Heim, A. Brech, J. Delabie, Blood, 118 (2011) 3331-3339.

[12] C. Luo, D. Tsementzi, N. Kyrpides, T. Read, K.T. Konstantinidis, PloS one, 7 (2012) e30087.

[13] M. Meyer, U. Stenzel, S. Myles, K. Prufer, M. Hofreiter, Nucleic acids research, 35 (2007) e97.

[14] Y.C. Wu, D. Kipling, D.K. Dunn-Walters, Frontiers in immunology, 2 (2011) 81.

[15] Y.C. Wu, D. Kipling, H.S. Leong, V. Martin, A.A. Ademokun, D.K. Dunn-Walters, Blood, 116 (2010) 1070-1078.

[16] E. Alamyar, P. Duroux, M.P. Lefranc, V. Giudicelli, Methods Mol Biol, 882 (2012) 569604. 
[17] E. Alamyar, V. Giudicelli, S. Li, P. Duroux, M.P. Lefranc, Immunome research, 8 (2012) 26.

[18] E. Gasteiger, C. Hoogland, A. Gattiker, S. Duvaud, M.R. Wilkins, R.D. Appel, A. Bairoch, Protein Identification and Analysis Tools on the ExPASy Server; (In) John M. Walker (ed): The Proteomics Protocols Handbook, Humana Press, (2005) 571-607.

[19] R Development Core Team, R Foundation for Statistical Computing, Vienna, Austria, (2010) ISBN 3-900051-07-0.

[20] R.C. Gentleman, V.J. Carey, D.M. Bates, B. Bolstad, M. Dettling, S. Dudoit, B. Ellis, L. Gautier, Y. Ge, J. Gentry, K. Hornik, T. Hothorn, W. Huber, S. lacus, R. Irizarry, F. Leisch, C. Li, M. Maechler, A.J. Rossini, G. Sawitzki, C. Smith, G. Smyth, L. Tierney, JY. Yang, J. Zhang, Genome Biol, 5 (2004) R80.

Figure 1. Schematic presentation of immunoglobulin gene cDNA showing the primer binding sites for CDR-H3 spectratyping.

Figure 2. Schematic representation of immunoglobulin gene cDNA and primer binding sites for HTS, semi-nested PCR.

Figure 3. Diagram to illustrate the PCR amplicon sizes of different IGH isotypes, IGL and $I G K$, in relation to the Hyperladder IV DNA size marker, on a 1.5\% TAE agarose gel. 